\title{
Adalberto Paranhos
}

\section{A CRUZADA DA PURIFICAÇÃO NACIONAL CONTRA A BOSSA NOVA: ECOS DE UM DEBATE}

\section{RESUMO}

Tempos atrás, Elomar, o cantador das caatingas, exprimiu toda a sua insatisfação em relação à Bossa Nova, um caso explícito, segundo ele, de "puxa-saquismo cultural" de quem resolveu "jazzar o samba" para entrar no mercado norte-americano. Este artigo procura evidenciar que ouvir Elomar falar equivale a comprar um bilhete para uma viagem sem volta rumo ao passado, pois suas palavras representam, sob vários aspectos, um eco tardio de argumentos esgrimidos por nacionalistas ferrenhos, a exemplo do pesquisador e jornalista José Ramos Tinhorão e outros mais. No rastro do sucesso da Bossa Nova, entre o fim dos anos 1950 e a década de 1960, a reação se instalou e estalou, pondo em movimento uma verdadeira cruzada de purificação da música popular brasileira, uma versão à moda da casa de uma espécie de "nazismo cultural". Este texto, escrito fora dos padrões acadêmicos mais ortodoxos, mergulha, a partir da crítica às formulações de Elomar, no debate do período em torno da Bossa Nova. Dirigido especialmente a não iniciados na matéria, ele, tal como aparece aqui, é um fragmento inicial de um longo artigo, publicado em 1990, sem nunca haver chegado até hoje aos meios de comunicação digital.

Palavras-chave: Samba e jazz. Bossa Nova. Nacionalismo musical. 


\section{A CRUSADE OF NATIONAL PURIFICATION FROM BOSSA NOVA: ECHOS OF A DEBATE}

\section{ABSTRACT}

Some time ago, Elomar, the singer of the caatingas (Caatinga biome) -, made public his dissatisfaction towards Bossa Nova, which is, from his point of view, an explicit instance of "cultural toadyism" from whom decided to jazz up Samba in order to enter the American music market. This article aims to make evident that listening to Elomar's complaints is the same as buying a one-way ticket to the past, since his words represent, in many respects, a belated echo of arguments once advanced by staunch nationalists, such as José Ramos Tinhorão, a scholar and journalist, and many others. In the wake of the success of Bossa Nova, between the end of the 1950s and the decade of 1960, reactionary groups organized themselves and launched a crusade whose main objective was to purify Brazilian popular music, an action which resembled some sort of "cultural Nazism". This text, written outside the most orthodox academic standards, dives into the debate of the Bossa Nova period, departing from a critique of Elomar's formulations. Addressed to those not versed in the matter, this piece is part of a longer article, published in 1990, which has never reached digital platforms until now.

Keywords: Samba and jazz. Bossa Nova. Musical Nationalism.

\section{LA CRUZADA DE LA PURIFICACIÓN NACIONAL CONTRA LA BOSSA NOVA: ECOS DE UN DEBATE}

\section{RESUMEN}

Hace tempo, Elomar, el cantante de las caatingas, expresó toda su insatisfacción en relación a la Bossa Nova, un caso explícito, según él, de "adulación cultural" de quien resolvió "jazzar el samba” para entrar en el mercado norteamericano . En este artículo se busca evidenciar que oír a Elomar hablar equivale a comprar un billete para un viaje sin retorno hacia el pasado, pues sus palabras representan, en varios aspectos, un eco tardío de argumentos esgrimidos por nacionalistas férreos, a ejemplo del investigador y periodista José Ramos Tinhorão y otros más. En el rastro del éxito de la Bossa Nova, entre finales de los años 1950 y la década de 1960, la reacción se instaló y estalló, poniendo en movimiento una verdadera cruzada de purificación de la música popular brasileña, una versión a la moda de la casa de una especie de "Nazismo cultural". Este texto, escrito fuera de los estándares académicos más ortodoxos, se sumerge, a partir de la crítica a las formulaciones de Elomar, en el debate del período en torno a la Bossa Nova. Dirigido especialmente a no iniciados en la materia, él, tal como aparece aquí, es un fragmento inicial de un largo artículo, publicado en 1990, sin nunca haber llegado hasta hoy a los medios de comunicación digital.

Palabras clave: Samba y jazz. Bossa nova. Nacionalismo musical. 
Bossa Nova, samba-jazz

Sambalanço ou samba só

O que importa é que o balanço é bom [...]

Balançando viajou

Balançando ele provou

Que esse mundo não é quadrado, não

"Samba só"

(Walter Santos e Tereza Souza)

\section{EXPLICAÇÃO INTRODUTÓRIA}

Este texto, duplamente datado, é republicado aqui quase 28 anos após haver sido dado à luz. Por que datado? Em primeiro lugar, porque data do outono de 1990, como decorrência de uma incursão num debate cujo mote foi uma entrevista concedida por Elomar, na qual ele desancava a Bossa Nova. Tratei, então, de evidenciar como tais críticas se afinavam, em larga medida, pelo mesmo diapasão de José Ramos Tinhorão e outros nacionalistas de plantão, que concebiam a produção musical bossa-novista como expressão de um impulso artístico de lesa-brasilidade.

$\mathrm{O}$ artigo, escrito em linguagem que, em muitas passagens, transgride os padrões habitualmente aceitos na academia, nutriu-se de um objetivo polêmico. Embora aluda a determinados autores e obras, dispensei-me da obrigação de amarrá-lo a certos penduricalhos acadêmicos. Interessava-me, acima de tudo, não poluí-lo com esse tipo de procedimento, animado pelo propósito de torná-lo mais fluente, quando mais não seja porque seu público-alvo era, em especial, o leitor não iniciado nessa discussão. Recheei-o, isso sim, de um grande número de notas, sem dúvida, porém, como adverti, à época, numa observação preliminar, "apesar da alta dose de arbitrariedade desta decisão, optei por citar, mais ou menos abundantemente, ao longo deste trabalho, aquilo que possa constituir o que designei de notas musicais, ou melhor, referências encontradas em disco". Sem maiores pretensões teóricas e analíticas, moveu-me a intenção de condensar boa parte das conclusões apresentadas por uns tantos estudiosos da Bossa Nova, o que não implicou, contudo, renunciar por inteiro à tentativa de incorporar também algumas contribuições pessoais. Mas a principal finalidade das muitas notas de rodapé acopladas ao artigo consistia em fornecer um roteiro discográfico a quem não estivesse mais familiarizado com a Bossa Nova. Para esta reedição, no entanto, busquei atender às exigências acadêmicas de praxe, com a menção, comme ll faut, às indicações mais precisas sobre os textos dos quais me servi e suas referências complementares.

Nem por isso procurei suprir problemas que envolvem a segunda razão pela qual esta é uma obra datada. Não me dispus a incorporar a vasta bibliografia que, de meados de 1990 até hoje, foi produzida sobre a Bossa Nova. Assumir tal tarefa desfiguraria o artigo, que, com as suas limitações, deve ser encarado, efetivamente, como uma produção intelectual que se inscreve naquele e não neste tempo. De todo modo, de lá para cá, depois de esgotados os 1.000 exemplares impressos da edição no 3 de História \& Perspectivas (Uberlândia, jul.-dez. 1990, p. 5-111) que o acolheu, chegaram-me com frequência pedidos de cópias do texto (que, coisas do século passado, foi datilografado em máquina elétrica e nunca disponibilizado pelas infovias). Pesquisadores da Bossa Nova, desde graduandos a doutores ou pós-doutorandos, continuaram a demandar sua reprodução ou republicação. Nesse meio-tempo, Kátia Rodrigues Paranhos (UFU), Miliandre Garcia (UEL), Cleodir Morais (UFPA) e André Rocha Leite Haudenschild (ex-Udesc), aos quais sou muito grato, insistiram na conveniência de retirá-lo do ineditismo digital. A gota d'água, nesse processo de meu convencimento, veio com Herom Vargas (Umesp) e Mozahir Bruck (PUC-Minas), que publicaram recentemente na revista Matrizes, editada na USP, o trabalho "Entre ruptura e retomada: crítica à memória dominante da bossa nova”, disponível em https://www.revistas.usp.br/matrizes/ issue/view/10394.

Neste ano em que a Bossa Nova sopra suas 60 velinhas (o uso do diminutivo constitui uma de suas marcas), resolvi, enfim, sacudir a poeira e tirá-lo da toca. Antecipando-se a uma reedição total do artigo, talvez em e-book, acompanhado de uma introdução e de uma minifortuna crítica, o que agora se oferece à degustação dos leitores é um simples aperitivo. Amputado, ele ressurge, aqui, reduzido às primeiras páginas de um texto 
que, originalmente, se estendeu por longas 107 páginas. Nessa operação de encolhimento, deixei de lado os tópicos que se seguiriam: "Vira o disco: a revolução sonora da Bossa Nova," "Múltiplas faces de um mesmo rosto", "Num cantinho um violão e um novo canto", "Outras palavras", "Made in Brazil", "A 'desalienação' da Bossa Nova e a subida do morro", "Morte e vida da Bossa Nova" e "Tradição e contemporaneidade na MPB”. Eles anunciam, por assim dizer, cenas dos próximos capítulos, histórias que, como se fossem destiladas em conta-gotas, ficam para uma outra vez. Antes de pôr um ponto final nesta nota, não poderia faltar, obviamente, uma palavra de agradecimento ao editor da Revista de Estudos Culturais, Luiz Eduardo Oliveira. Dele recebi todo estímulo e compreensão para trazer de novo à boca da cena este fragmento de artigo que jazia submerso, apartado do mundo digital. O pinto quebra, finalmente, a casca do ovo. E isso, para mim, se reveste de um significado afetivo todo particular. Pudera! Ao escrevê-lo - um ato de curtição e de devoção à Bossa Nova -, eu não era mais do que um diletante apreciador de música. Não passava pela minha cabeça que, um dia, uma parcela substancial das minhas atividades de pesquisa gravitaria em torno das relações entre política, história e cultura, com ênfase na canção popular. Este é, intelectualmente falando, meu filho primogênito, pois foi a primeira vez que eu pari um texto sobre música popular. E a primeira vez a gente não esquece jamais (AP).

A vida não costuma ser fácil para aqueles que se insurgem contra tradições solidamente estabelecidas e, alheios aos dogmatismos, passam a interrogar as evidências de uma época. João Gilberto e João Donato que o digam. Antes da Bossa Nova tomar de assalto a moderna cena musical brasileira, a partir do sucesso de "Chega de saudade", com João Gilberto, exigia-se dos novos músicos em formação muita ginga e perseverança para driblar as dificuldades impostas pela tradição.

Aí pela segunda metade dos anos 50, os dois João foram convidados para uma série de shows numa estância hidromineral mineira. O que estava em princípio agendado para ser uma temporada reduziu-se, tragicamente, a uma noite de um show só. Ao final da primeira e única apresentação, o empresário chamou João Gilberto e João Donato a um canto e os despachou: "Vocês vão receber tudo direitinho, mas, por favor, não toquem mais". Donato, que cuidava de acompanhar João Gilberto ao piano, hoje se lembra desse episódio sem perder o bom humor:

Foi num desses lugares que têm água mineral. Conclusão: a gente ficou lá, já que o hotel estava pago e estava com dinheiro no bolso. Foi um porre geral de água mineral. Aliás, uma dor de barriga danada. Veja você como são as coisas: hoje em dia, João só canta onde quer, quando quer e da maneira que quer (Donato, 1989, p. 20).

Ambos já estavam, afinal, acostumados aos narizes torcidos e às orelhas em pé diante do som que extraíam de seus instrumentos, no caso, piano, violão e voz. Quantas vezes, na própria Copacabana que assistia à gestação da Bossa Nova, João Donato, ao se oferecer para dar uma canja (tocar de graça, na gíria musical), era aconselhado pelo proprietário de boate: "Deixa primeiro esvaziar um pouco" (id.), o que o condenava a tocar depois das 4 da manhã. Várias vezes, sentados à beira da calçada do Copacabana Palace, não restava a João Gilberto e a João Donato senão maldizer a incompreensão das pessoas sintonizadas com as sonoridades instituídas.

Recordo aqui esses acontecimentos porque, seja lá como for, eles não fazem parte de um passado soterrado. Basta atentar para as palavras de Elomar em uma de suas últimas andanças por Minas Gerais. Ao ler entrevista concedida em Uberlândia pelo cantador das caatingas (Elomar, 1987, p. 11), imediatamente voltei a pensar num fenômeno de que tanto já se falou e do qual talvez nunca se falará o suficiente: a dificuldade de sermos contemporâneos do nosso próprio tempo. Quantos de nós, agarrados a modelos envelhecidos de pensamento, ação e gosto, não opomos resistência, aqui e ali, a novas experiências no campo da existência humana, a ponto de nos tornarmos, por vezes, cegos e 
surdos às exigências de busca de novas alternativas de vida?

Isso se aplica, em termos gerais, a todos os aspectos das nossas vidas, inclusive ao terreno musical. Quando o tema é música popular brasileira, MPB ou coisa que o valha, muitos são aqueles que, trafegando na contramão de certas conquistas musicais históricas, pedem passagem para sair em defesa da "nossa tradição musical", da "identidade musical brasileira”. Na prática essa postura implica, normalmente, congelar uma determinada concepção que se tem sobre o passado e conduz à tentativa de paralisia da procura de novas formas de expressão e satisfação estética. Tradição e identidade cultural se convertem, portanto, em senhas a partir das quais frequentemente se tenta barrar o trânsito rumo ao novo.

\section{TUPI OR NOT TUPI}

Ao evocar o início de sua carreira em disco, em 1967, Elomar declara ter aparecido "imprensado entre dois rolos compressores". E arremessa seus petardos contra esses dois alvos, por ele considerados "duas grandes pinoias": "um, o tal do iê-iê-iê, e, outro, uma tal de Bossa Nova". Mas, na verdade, sua implicância maior se dirige contra a Bossa Nova. Elomar bate fundo: "ela é uma espécie de tentativa de um pacto cultural nosso com o estrangeiro". Mais ainda: "para entrar nos Estados Unidos, num puxa-saquismo danado, subserviência, eles [os autores da Bossa Nova] pegaram o samba e enfeitaram de jazz, 'jazzaram' o samba para entrar em Nova Iorque" (id.). Em síntese, com a Bossa Nova aqui jaz o samba...

Não exatamente por acaso, ouvir Elomar falar equivale a fazer uma viagem pelo tempo, irremediavelmente em direção ao passado, ou melhor, a uma concepção de passado musical que ele e outros mais erigem em "memória nacional". Sua entrevista nos leva de volta sobretudo à década de 60, um momento particular de efervescência cultural no Brasil e no mundo. Entrincheirados em suas cidadelas, os tradicionalistas (não seria preferível "tradinacionalistas"?), os puristas, ardorosos defensores das nossas "raízes musicais", se imaginavam atacados de todos os lados por uma espécie de conspiração interna- cional que punha em xeque o que havia de mais "genuinamente nacional" na música popular brasileira. Com o cruzado José Ramos Tinhorão à frente - historiador e crítico musical nacionalista que esteve no centro de muitas polêmicas desencadeadas na época - empreendeu-se uma verdadeira "cruzada da purificação". Essa corrente recrutou adeptos, como não poderia deixar de ser, até em setores da esquerda, cujo casamento histórico com o nacionalismo, embora não tenha tido um final feliz, gerou muitos rebentos, do qual foi expressão inclusive parte da produção da música de protesto (música que era também uma maneira de botar "todos os fracassos nas paradas de sucessos", como diria, num outro contexto, Caetano Veloso em "Épico"). Ora, a entrevista de Elomar, qualquer que seja o lugar específico que ele ocupe nesse debate, soa hoje como um eco tardio de um momento já vivido.

Na realidade, a Bossa Nova - para não entrar aqui na análise da versão tupiniquim do rock'n'roll, o iê-iê-iê da Jovem Guarda - incomodava aos ouvidos educados de acordo com as sonoridades tradicionais. Num período em que, alimentado pelos mitos do nacionalismo gerados pelo nacional-populismo e pelo desenvolvimentismo, o binômio nação $\mathrm{x}$ antinação comandava $\mathrm{o}$ pensamento, a ação e o gosto musical de muita gente, a Bossa Nova seria a tradução, na área musical, do processo de desnacionalização em curso. Selava, nas palavras de Elomar, um "pacto cultural com o estrangeiro". O jazz, aliado à "distorção" do samba, teria parido um monstro, estranho às "nossas tradições musicais". Nessa visão, assentada num maniqueísmo típico de um nacional-populismo primário, o estrangeiro, no caso a música estrangeira, consistia na encarnação do Mal; era urgente resgatarmos o Bem, bebendo nas fontes "puras" (comumente associadas ao morro) onde jorravam "o autêntico, o popular, o nacional". A xenofobia adquiria novas expressões. Mudava de nome, enfim.

Muitos são os exemplos disponíveis da "ira santa" que se apoderou de disc jockeys e pesquisadores identificados com a "velha guarda". Moraes Sarmento, cujo program pela Rádio Bandeirantes, do gênero hora da saudade, animava as noites paulistanas, com ressonância por todo o Brasil, via na Bossa Nova um movimento 
de lesa-brasilidade e se esforçava por acordar lembranças semiadormecidas. Na contracapa do LP Saudade em forma de samba, de Roberto Silva, a sua apresentação se equipara a um grito de guerra:

Sambas de verdade, sem truque, sem sofisticação! Sambas do tempo em que o samba era samba! Do tempo em que as fábricas de pandeiro davam lucro... [...] Daqueles mesmos sambas que os 'entendidos de hoje' chamam de quadrado, mas que na realidade, queiram ou não, são sambas autenticamente nossos, legítimos, sem a presença da famigerada 'macacobraz', tão a gosto dos 'entendidos de hoje', que procuram denegrir aquela maneira verdadeira de como se cantava ou compunha um samba realmente brasileiro (Sarmento, 1966).

Macacobraz, ressalte-se, era expressão de largo uso no vocabulário de Moraes Sarmento, e sua intenção crítica se voltava contra tudo que, a seu ver, cheirava a cópia, postiço, imitação, inadequação à nossa realidade cultural. Numa palavra, aproximadamente o mesmo que o crítico literário Silvio Romero (1897, p. 121-123) queria dizer ao registrar que a "macaqueação" era fato social dominante nos tempos pós-coloniais, especialmente no $2^{\circ}$ reinado.

Esse tipo de "racio-símio" ganhou destaque no período pós-surgimento da Bossa Nova. Atordoado pelos efeitos da gravação de "Chega de Saudade", por João Gilberto, o pesquisador musical Lucio Rangel lhe contraporia, no final dos anos 50, a "interpretação sincera e brasileira" de Roberto Silva, sem "recursos exóticos". Muito preocupado com as "raízes" - ele próprio musicalmente conservador até a raiz do cabelo, sem se dar conta de que as verdadeiras raízes estão no Jardim Botânico -, Lucio Rangel enaltecia as virtudes do intérprete que apresentava: "Eis um cantor que, felizmente, canta à velha e autêntica maneira; ele não prende a voz, não canta 'pra dentro', não sussurra" e, ainda por cima, se move ao som de um "ritmo cem por cento brasileiro" (contracapa dos LPs Descendo o morro, de 1958, e Descendo o morro, $n^{\circ} 2$, de 1959). E por aí poderíamos ali- nhar inúmeros exemplos de irritação provocada pela Bossa Nova. Quantas "sambesteiras" não foram proclamadas na vã ilusão de preservar o samba diante do perigo representado por elementos "exógenos". Decorridos uns tantos anos, Sargentelli, por exemplo, continuava a desconsiderar a Bossa Nova. Para ele "samba tem que ter ziriguidum", ser "samba da pesada"; por isso não admitia nenhuma convivência pacífica com o "samba gago", característico do "violão na base da gagueira" (conforme sua participação no LP de Nelson Cavaquinho, Depoimento do poeta, de 1970).

Mas a luta contra a Bossa Nova nos anos 60 encontrou seu maior expoente em José Ramos Tinhorão. Despertando reações de amor e ódio, esse estudioso das manifestações musicais brasileira não contemporizava em suas críticas. Na sua obra mais difundida, Pequena história da música popular: da modinha ao tropicalismo, ele, mais uma vez, insistia: "Historicamente, o aparecimento da bossa nova na música urbana do Rio de Janeiro marca o afastamento definitivo do samba de suas fontes populares" (Tinhorão, 1986, p. 230). Para Tinhorão, os jovens de classe média alta da zona sul carioca que produziram a Bossa Nova eram "completamente desligados" (id., p. 231) das nossas tradições musicais populares. Mais do que isso, eles encarnaram uma nítida divisão de classe na música popular brasileira: de um lado, os ritmos e canções populares que provinham das camadas urbanas mais baixas, de outro, a alta sofisticação dos signos musicais da alta classe média. E, sem fazer segredo do economicismo que pontua o seu pensamento de homem de esquerda, Tinhorão resumia sua visão do panorama musical do Brasil: "Dividida assim em duas grandes tendências, a partir da década de 60, a música popular urbana passou a evoluir numa perfeita correspondência com a situação econômico-social dos diferentes tipos de público a que se dirigia" (id., p. 236). Nesse contexto, a Bossa Nova, no fundo, se reduziria a "um exemplo (não conscientemente desejado) de alienação das elites brasileiras" (id., p. 231). Por essas e outras Caetano Veloso, muito jovem ainda, porém profundamente envolvido nos debates sobre os caminhos da MPB, contra-atacou quando Tinhorão lançou, em 1966, Música Popular: um tema em debate: "o livro de Tinhorão defende a preservação 
do analfabetismo como uma única salvação da música popular brasileira" (Veloso, 1966, p. 378). Tupi or not tupi, that is the question, parecia afirmar Tinhorão, numa adaptação da conhecida fórmula de Oswald de Andrade (1928) ao seu nacionalismo estético estreito.

A discussão corria acalorada. Para uns, como frisou recentemente Elomar em entrevista no programa "Arrumação", da TV Minas, o distanciamento das fontes populares se explicava essencialmente pela subjugação da MPB aos "elementos envenenantes do jazz, que mina as bases culturais do povo". Para outros, situados no extremo oposto, o "nacionalismo nacionalóide" da Tradicional Família Musical (TFM, por alusão ao reacionarismo da TFP) perdia de vista a necessidade da criação de uma música "nacional universal", no dizer de Augusto de Campos (1986, p. 14). Intelectual às voltas com a produção da poesia concreta desde meados dos anos 50, ele lançou na década de 60 o célebre Balanço da Bossa e outras bossas. Nele investia, implacável, "não contra a Velha Guarda. Noel Rosa e Mário Reis estão muito mais próximos de João Gilberto do que supõe a TFM. Contra os velha-guardiões de túmulos e tabus. Idólatras dos tempos idos" (id., p. 14-15).

A influência do jazz no surgimento da Bossa Nova não tinha como - aliás, nem por que - ser negada. No pré58 o Beco das Garrafas, em Copacabana, era tomado por jam sessions. Músicos da maior importância, de João Donato a Luiz Eça, reconheciam seu débito para com as harmonizações jazzísticas. O Songbook Bossa Nova (1989), editado há pouco tempo, confirma-o novamente, se é que alguém ainda mantinha dúvidas a respeito disso. Luiz Eça, por exemplo, maestro, arranjador, líder do Tamba Trio e pianista de primeira linha, nunca fez a menor questão de esconder as influências recebidas de Art Tatum, Errol Garner, Oscar Peterson e Bill Evans.

Mas, a partir de determinado momento, mais precisamente em 1962/63, a reação à "jazzificação" do samba se instalou dentro do próprio movimento bossa-novista, uma evidência de que a oposição samba x jazz não refletia apenas o ponto de vista dos que eram contra ou a favor da Bossa Nova. A realidade se apresen- tava algo mais complexa, incapaz de ser submetida a esquemas analíticos simplistas. Contraditoriamente, Carlos Lyra, um dos mais fecundos compositores da Bossa Nova, fez soar seu grito de alerta em "Influência do jazz", que alcançou ampla repercussão:

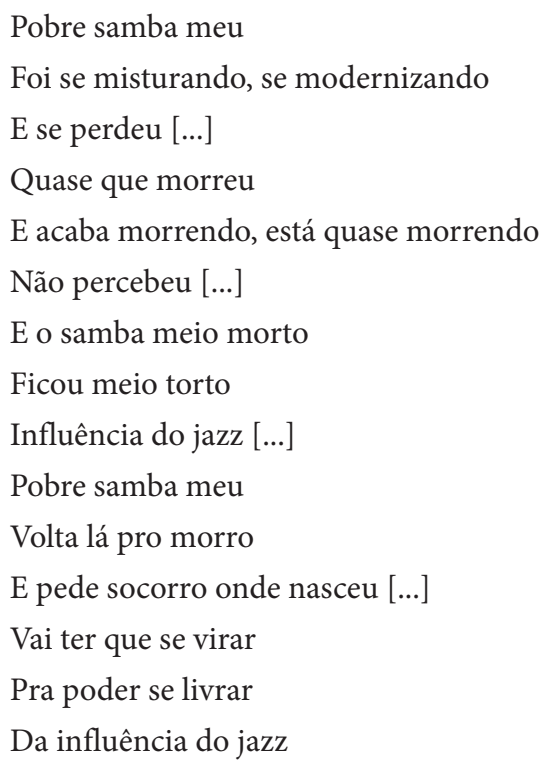

E a música, calcada nas características da Bossa Nova, colidia intencionalmente com a letra, que traía o militante Carlos Lyra, vinculado ao Centro Popular de Cultura (CPC) da União Nacional dos Estudantes (UNE).

Estava aberta, por assim dizer, a diáspora no interior do movimento. Obviamente não se tratava de uma manifestação nacionalista isolada. No contexto do nacional-populismo a busca obsessiva da recuperação do "popular" e do "nacional" contagiava outras áreas da cultura. A poesia, para ficar num único exemplo, via nascer o Violão de rua (1962/1963), cujas publicações se sucediam por intermédio da Editora Civilização Brasileira. O cenário musical não permanecia nem um pouco indiferente ao debate que eletrizava sobretudo setores das classes médias urbanas. Nelson Lins e Barros, ao escrever para Movimento, órgão da UNE, em 1962, já punha à mostra sua proximidade estético-ideológica com Tinhorão, embora houvesse se engajado como letrista na onda bossa-novista. Para ele a Bossa Nova corporificava a música da alta classe média e, nesse sentido, "é a expressão de uma classe que pouco tem em comum com as classes populares, com o agra- 
vante de sofrer influência da música estrangeira”. O jornalista Franco Paulino, ao apresentar o LP de Vandré, 5 anos de canção, em 1966, batia na mesma tecla: "A verdade é que, quando Geraldo Vandré apareceu compondo, a música popular brasileira estava ficando cada vez menos brasileira e muito menos popular".

Não era de se estranhar, portanto, que Tinhorão desdenhasse o maior compositor da Bossa Nova, Tom Jobim, até por não entender como ele poderia chamar-se Antonio Carlos Brasileiro [!] de Almeida Jobim... O "internacionalismo" bossa-novista, presente tanto na incorporação de recursos da música popular dos Estados Unidos quanto da música erudita, desaguara, para esse historiador, numa música antinacional, "o que correspondia, no plano econômico, à tentativa de industrialização do país com uso de tecnologia importada" (Tinhorão, 1986, p. 237). Esse viés economicista de análise faria escola e se conservaria por um bom tempo. Em 1968, por exemplo, nas páginas da Revista Civilização Brasileira, outro compositor, Sidney Miller, sociólogo e letrista premiado em festival da TV Record, discorria sobre "O universalismo e a música popular brasileira”. Apoiado em considerações de Nelson Lins e Barros, que exercera a função de coordenador da seção de música da $R C B$, ele encarava a Bossa Nova como "uma exigência imposta por um aumento do poder aquisitivo da classe média, consequência da política desenvolvimentista dos anos 50, coroada pelo governo JK” (Miller, 1968, p. 208).

Ainda hoje é necessário contrapor a esses simplismos outro tipo de explicação. De fato, a partir da década de $4 \mathrm{O}$ os circuitos internacionais da indústria cultural interligaram cada vez mais as diferentes partes do mundo, um vasto mercado que se abriu particularmente à penetração da indústria fonográfica norte-americana e, com ela, do jazz. Com a supremacia global do capitalismo norte-americano que se configurou no pós-Segunda Guerra Mundial, a música "made in USA", vinda no seu rastro, ganhou mais adeptos. E influenciaria os bossa-novistas, muitos dos quais seus admiradores confessos. Agora, deduzir daí, à moda de Tinhorão (1990), que o capitalismo norte-americano tenha como que inventado a Bossa Nova consiste em acreditar num tal automatismo das forças de mercado que reduz os agentes da criação da Bossa Nova a meros produtos (manipuláveis) de necessidades econômicas. Enfim, a nova correlação de forças dentro do sistema capitalista internacional, a exportação da música norte-americana e a existência de uma classe média urbana com poder aquisitivo e nível de informação cultural mais sofisticado são condições que ajudam a explicar o surgimento da Bossa Nova, mas não o determinam por imposição cega das forças de mercado. Assumir essa concepção economicista equivale a colocar os homens totalmente a reboque de fatores irresistíveis e, no caso específico, passar por cima de outros condicionantes fundamentais ligados à formação cultural e musical brasileira que, em hipótese alguma, podem ser negligenciados.

Acusados de "entreguismo musical", responsabilizados pela "deturpação" do samba, os jovens de classe média urbana afinados com as origens da Bossa Nova responderam a isso tudo com humor e provocações. Walter Santos e Tereza Souza estavam entre os que não se davam por vencidos. E esgrimiam, alegremente, os seus argumentos em "Samba só", a contraface de "Influência do jazz":

\author{
Bossa Nova, samba-jazz \\ Sambalanço ou samba só \\ O que importa é que o balanço é bom \\ Interessa é balançar \\ Bossa Nova ou samba-jazz \\ Nosso samba agora está demais \\ Ai, meu samba, fizeram tanta confusão \\ Disseram que você desafinava \\ Ai, meu samba, quanta ingratidão [...] \\ Balançando viajou \\ Balançando ele provou \\ Que esse mundo não é quadrado, não
}

\section{OS RISCOS DA APROPRIAÇÃO/EXPROPRIAÇÃO DO PASSADO}

Qualquer historiador não contaminado pelo vírus do positivismo sabe que a história, tal qual a escrevemos, constitui uma construção humana. Os fatos históricos carregam consigo a subjetividade de quem os vê, de quem os interpreta, de quem julga o que é ou não rele- 
vante em meio a documentações e registros dispersos, os quais, por sua vez, não passam, igualmente, de produções humanas de caráter social.

Se assim é, podemos questionar, em primeiro lugar, face ao discurso nacional-tradicionalista arraigado nos padrões de julgamento da música popular brasileira, o que autoriza certos guardiões da "pureza nacional", à la Ary Barroso, a fazerem uns tantos cortes com base nos quais se separa o "autêntico" do "inautêntico". Muitas vozes tornaram a se levantar, em fins da década de 60 , contra o Tropicalismo, inclusive a esquerda tradicional, porque - escorados, entre outros, na usina sonora do maestro Rogério Duprat e do guitarrista Lanny Gordin - Caetano Veloso, Gilberto Gil, Torquato Neto, Tom Zé, Capinan, Gal Costa e outros mais ousaram revolucionar a poética cantada e os modelos musicais vigentes. Absorvendo influências do rock, eles promoveram a eletrificação da MPB com a estridência das guitarras que aturdia os tímpanos conservadores. Isso seria uma conspiração contra as "nossas tradições".

Mas de que tradição se estava falando? Certamente de uma tradição particular, por sinal muito rica, associada à cuíca, ao pandeiro, ao violão, ao samba, cujas origens, é preciso recordar, não são "puramente nacionais". Essa tradição, legitimada como "autêntica", deliberadamente ou não, ocultava, por exemplo, para não irmos muito longe, a já tradicional - se bem que regional - música eletrificada que rolava pelas ruas de Salvador com o aparecimento da Dupla Elétrica de Dodô e Osmar, às vésperas do carnaval de 1950. Data daí sua evolução em direção aos trios elétricos, instrumentos da eletrificação do carnaval baiano, momento contagiante de democracia social.

Como toda escolha é seletiva, afirmar uma tradição implica negar outras tantas tradições. Afinal de contas, o passado, tal como o presente, não é unívoco, unilinear. Pelo contrário, ele envolve diferentes sentidos, múltiplas perspectivas. Ao elegermos uma ou algumas delas como as autênticas, procedemos a um julgamento com um grau considerável de arbitrariedade. A apropriação do passado sempre tem muito a ver com a expropriação de determinados aspectos do passado. As falas dominantes se impõem a partir dos dispositivos do poder de silenciar ou asfixiar as outras falas.

Em segundo lugar, convém problematizar e/ou relativizar a própria valorização da tradição, independentemente do seu caráter seletivo. Até que ponto as "nossas mais caras tradições" não podem funcionar como autênticas camisas de força, obrigando-nos à submissão aos voos rasantes da criatividade artística, aprisionando-nos a imaginação? Se a Bossa Nova alargou sensivelmente as margens do possível na música popular brasileira, preparando terreno inclusive para o advento da Tropicália, aí pelo final de 1967, ela teria necessariamente de agitar as águas estagnadas em que iam beber muitos dos zeladores da "cultura nacional". Ao romper com uma visão anacrônica sobre a tradição, a Bossa Nova contribuiu poderosamente para apagar a linha que divide os campos do "nacional" e do "estrangeiro". Por outras palavras, atualizou o Brasil no cenário musical internacional, ou, para ir direto ao assunto, agrediu o nosso provincianismo. Provincianismo de aldeia, acrescente-se, como confessa, orgulhoso, Elomar (1987, p. 11): "Acho que cada cantor deve cantar para sua aldeia. Se extrapolar as desinências de sua aldeia e chegar em outras aldeias, beleza! Agora, eu fazer música para gringo ouvir, por quê? O que é que tem a ver comigo? Nada".

O culto à tradição, combinado à tentativa de resgate da "pureza original" da música popular brasileira, continha, além de tudo o que se viu, um elemento perturbador. Estávamos, no fundo, diante de uma espécie de nazismo e/ou arianismo cultural. A busca de formas puras, a incapacidade para se dar conta de que a arte é impura, o apego a uniformes sonoros e a uniformidades denunciavam o autoritarismo subjacente a essas posições. Um como que fechamento das fronteiras culturais para isentar a "nossa música" de contatos "espúrios" com a produção internacional comporta óbvios paralelismos com o "nacional-socialismo". Aliás, Gilberto Gil se referiu à "ingenuidade nazista" que impulsionava opositores da Bossa Nova na sua perseguição daquela "coisa pura, brasileira num sentido mais folclórico, fechado, uma coisa que só existisse para a sensibilidade brasileira" (Gil, 1986, p. 190). A sanha purificadora de Tinhorão, por exemplo, 
não poupou nem Paulinho da Viola, a quem acusaria, nos anos 70, de ter deformado um samba de Nelson Cavaquinho. Paulinho, enfim, não só não acreditava na existência de formas puras no samba como ainda achava "esse negócio de autêntico muito perigoso".

Não é de hoje que se valorizam o "primitivismo" e o "purismo", elos de uma mesma cadeia de concepções. $\mathrm{Na}$ perspectiva romântica ambos se ligam umbilicalmente à "cultura popular", como território das tradições do povo cuja preservação originou toda uma plataforma cultural. Como esclarece Marilena Chaui (1986) em seus estudos sobre o tema, a abordagem romântica parte do pressuposto da autonomia da cultura popular, encarnação de uma cultura "autêntica", por oposição à cultura dominante. E mais, atribui a um Estado novo e a uma nação nova a missão de recuperá-la e preservá-la à margem da contaminação e do contato "deletério" com o mundo da cultura oficial. Converte-se, assim, em solo propício para que aflorem populismos de todos os tipos. Na outra ponta da gangorra se situa a perspectiva ilustrada. No limite, a cultura popular é percebida como peça de museu e arquivo, restos de um passado em processo de decomposição. O tempo da "tradição" estaria irremediavelmente contado: a "modernidade" ditaria sua sentença de morte, e os elementos da "cultura tradicional" nem sequer reuniriam forças para gravar os seus efeitos sobre o curso da modernização.

A rigor, subsiste certa base comum a essas duas posições contrárias. Marilena Chaui (id., p. 24) aponta para isso: "Românticos e Ilustrados pensam a Cultura Popular como totalidade orgânica, fechada sobre si mesma e perdem o essencial: as diferenças culturais postas pelo movimento histórico-social de uma sociedade de classes". E o que me interessa reter, aqui, é que na luta político-cultural travada especialmente na década de 60 entre as correntes estéticas "nacional-popular" e "vanguardista", também denominada "formalista", tais posturas estarão presentes. De algum modo elas atualizarão umas tantas questões que já despontavam na Semana de Arte Moderna de 1922 no entrechoque de "verde-amarelos" e "antropofágicos". Seja como for, evidencia-se como, esteticamente, as concepções nacional-populistas desembocaram à direita pela via da esquerda... Por essa razão Sergio Paulo Rouanet (1988, p. D-3) chama atenção para o parentesco ideológico entre o "povo" do modelo "nacional-populat" dos anos 60 e o "volk" do romantismo alemão. O historismo, de origem conservadora, se transformou, no contexto cultural brasileiro, num historismo de esquerda. Nas palavras desse pensador, o historismo

está defendendo um patrimônio: a proprìedade, a tradição e a ordem social. Mas, por uma aberração que não é peculiar ao Brasil, o historismo foi apropriado pelo pensamento crítico, como coisa sua. O historista de esquerda combate o universal, porque o vê como agente da dominação. Ele se considera um rebelde, e expulsa o universal como quem expulsa um batalhão de "marines" (id.).

Daí enredar-se no apelo aos particularismos que encontram seu ponto de sustentação numa "individualidade coletiva: uma época, uma raça, um estamento, uma cultura" (id.).

Respirava-se naquele momento um ar saturado de tradicionalismos populistas, que se voltariam, com toda carga, contra a Tropicália, um pouco mais tarde. Sob esse clima é que se pode entender o significado da iconoclástica interpretação dos Mutantes da clássica "Chão de Estrelas", de Silvio Caldas e Orestes Barbosa, inserida no LP A divina comédia ou ando meio desligado, de 1970. Unindo os seus talentos ao de Rogério Duprat, eles fizeram dessa canção o bode expiatório na propositalmente ridícula metamorfose do sério em hilariante. Numa gravação onomatopaica, esses agentes provocadores dispararam - os tiros, aqui, são ao pé da letra - contra o culto à tradição, desfazendo-a em cacos. Esse papo já estava pra lá de qualquer coisa insuportável.

\section{PEQUENA HISTÓRIA DE ALGUMAS INCOMPREENSÕES}

A desmontagem dos andaimes tradicionais nos quais se apoiou e/ou se apoia a criação musical jamais foi tarefa fácil. Cabem aqui alguns paralelos, por exemplo, entre Debussy e a Bossa Nova. Como se sabe, Tom Jobim, 
entre as influências eruditas que assimilou em sua obra, nunca escondeu sua dívida para com Debussy, um mestre da dissonância que dispensava à música o tratamento de uma obra aberta. Até se impor e receber o devido reconhecimento por parte da crítica e dos músicos eruditos, ele amargou maus momentos. No final do século passado seus improvisos ao piano de séries de acordes dissonantes eram incompreendidos pelos burocratas de conservatório. Mais de uma vez foi visto e ouvido como "exótico" e tachado de "bárbaro". Assistia-se à batalha da dissonância versus consonância, antecessora de outro enfrentamento que se deslocaria para o campo dos ruídos versus "sons musicais". Não seria, pois, de se surpreender que dois gêneros musicais que se aproveitaram dos ensinamentos de Debussy, o cool jazz e a Bossa Nova, motivassem reações de inconformismo. Afinal, ambos, como assinala o crítico J. Jota de Moraes (1983, p. 100), "se encarregaram de 'trocar em miúdos' algumas das informações de Debussy”.

A história do jazz também está recheada de exemplos de incompreensões. Houve necessidade de remover muitas resistências para que o bebop, outra vertente jazzística cuja presença seria notada na Bossa Nova, fosse aceito como jazz. Quantos não foram os críticos e músicos, chegados à batida mais mecânica do swing que imperava nos anos 30 nos Estados Unidos, que repudiaram o beat do bebop como o antijazz, por terem como paradigma tão somente o jazz tradicional? O bebop, na década de 40, detonou uma revolução na música norte-americana e pagou seu preço pela ousadia de propor novas soluções musicais. Pai do jazz moderno, recairia sobre ele a fúria dos que o responsabilizavam bem como às distintas variantes do jazz dos anos 50 , às quais, de uma forma ou de outra, ele imprimiu a sua marca - pela distância que se cavou entre o jazz e o homem comum, como decorrência da crescente sofisticação dos produtos musicais jazzísticos. Em rota de colisão com os cultores do traditional jazz, os boppers, como aconteceria mais tarde no Brasil, reservavam a palavra square (quadrado) para se referir ao jazz pré-bop.

Mas não é preciso recorrer a exemplos tirados da história da música erudita ou do jazz para rastrear incompreensões tão frequentes ante o surgimento do novo.
No processo de constituição da tradição musical brasileira, o que atualmente é encarado como tal nem sempre o foi. Pixinguinha, quem diria?, uma das glórias da música do Brasil, em plenos anos $2 \mathrm{O}$ se tornou objeto de comentários nada elogiosos por haver absorvido a influência das jazz bands. Isso ficou claro após uma bem-sucedida temporada de 6 meses na Paris de 1922, onde o conjunto Les Batutas se exibia com Pixinguinha à flauta, ao lado de músicos que tocavam banjo, saxofone, clarineta, pistom e trombone, instrumentos pouco comuns às nossas tradições. Como se isso não bastasse, as fotos dos batutas mostravam, pela própria disposição dos músicos, poses caracteristicamente norte-americanas das jazz bands. Anos depois, um crítico musical, Cruz Cordeiro (Phono-Art, 1928-1929), denunciaria a influência da música norte-americana na melodia e inclusive na parte rítmica de "Lamento" e "Carinhoso", Apagados esses fatos da memória, em 1954 a Revista da Música Popular (p. 3), dirigida por Lucio Rangel e Pérsio de Moraes, dedicava a capa do seu número de estreia a Pixinguinha, saudado como símbolo do "autêntico músico brasileiro, o criador e verdadeiro que nunca se deixou influenciar pelas modas efêmeras ou pelos ritmos estranhos ao nosso populário". Ironias da história.

Bide e Ismael Silva, hoje recolhidos à galeria dos imortais da música popular brasileira, também não foram digeridos com a facilidade que se poderia supor. Estiveram na berlinda na virada dos anos $2 \mathrm{O}$ para os 30 , quando o samba, até então muito influenciado pelo maxixe dos fins do século XIX, foi cedendo espaço ao "samba de carnaval". Sinhô, com seu samba amaxixado, glorificado como "o rei do samba", descarregava sua ira contra Bide em 1930, estendendo suas críticas a todos os compositores "modernistas". E ele não falava simplesmente por si. Na verdade refletia o pensamento dos integrantes da "primeira geração do samba", insatisfeitos com as novidades introduzidas no "samba tradicional". Como disse o pesquisador Sérgio Cabral (1984, p. 1-2),

o que Sinhô, Donga \& Cia. não percebiam era que o novo samba resultava da necessidade de um tipo de música que servisse à nova realidade implantada pela escola de samba, que surgia no bairro do Estácio (onde 
moravam compositores importantes como Bide e Ismael Silva) e, rapidamente, se espalhava pelas favelas e pelos subúrbios do Rio de Janeiro.

Donga, por sinal, não economizou críticas a Ismael Silva pelo surgimento daquilo que viria a ser batizado como "samba carioca". Por essas e outras razões, não deixa de ser curioso constatar que onde antes se via a traição hoje se vê a tradição. A tal ponto que, com o passar do tempo, da própria Bossa Nova hoje se poderia afirmar que integra o que mereceria ser chamado de moderna tradição musical brasileira.

\section{TRANSVIADOS DO SAMBA}

A Bossa Nova não emergiu do nada. Compreender o seu aparecimento, como acontecimento musical, requer uma análise que com certeza vai se deparar com uma sucessão de desvios que compuseram o processo de sua formação. Esses desvios, muitas vezes censurados à época em que ganharam corpo, abriram caminho no interior da história da música popular brasileira para que, dialeticamente, o acúmulo de mudanças proporcionasse o salto qualitativo que instauraria o novo.

As composições de Garoto, violonista célebre, fazem parte do rol de contribuições que convergiram na direção da Bossa Nova. Ex-professor de violão de Carlos Lyra, ele tecia dissonâncias pioneiras na área da música popular, como o reconhecem, entre outros, o compositor Roberto Menescal e o doublé de compositor e produtor de disco (ex-líder do Bando da Lua) Aloysio de Oliveira, ambos figuras marcantes do movimento bossa-novista. O que falar, também, de Custódio Mesquita, cujas melodias já causavam estranheza? Simpatizante declarado da música norte-americana (notadamente o fox), para desagrado dos nacionalistas, ele inovou o samba-canção. Tom Jobim, por sua vez, por dever de gratidão, discorre, encantado, sobre o impacto que as músicas de Dorival Caymmi exerceram sobre ele. Carlos Lyra igualmente o aponta como um precursor da Bossa Nova. E Caymmi não deixa por menos: vincula as novidades que intuitivamente injetou na arte de compor ao trabalho ao violão de Laurindo de Almeida e Garoto. Seu depoimento é bastante elucidativo: "eles faziam aproximadamente o mesmo que eu, só que através do estudo. $\mathrm{Eu}$, por conta própria, sempre tive tendência de alterar os acordes perfeitos [...] procurando harmonia diferente. [...] Desde pequeno acho que o som deve ter outra beleza além do acorde perfeito" (apud Souza, 1982, p. 1). E nessa busca de percursores - tema permanentemente aberto à pesquisa - Sérgio Cabral (1989, p. 14) resgata do esquecimento, entre outros, o nome de Valzinho (Norival Carlos Teixeira), compositor e violonista que na década de 40 agredia a consonância no conjunto Bossa Clube, liderado por Garoto.

A Bossa Nova alterou profundamente o modo de cantar. Porém, mesmo nesse campo existem antecedentes que nos obrigam a recuar ao final dos anos 20 e ao início dos 30. Sobressai, então, o charme discreto de Mário Reis, que soube tirar partido como ninguém das transformações por que passavam as técnicas de gravação, evoluindo dos processos mecânicos de produção de discos até a incorporação dos processos elétricos. Ele percebeu que, com o advento do microfone, não era mais necessário apelar para a voz forte, tonitruante, para gravar os registros vocais nos cilindros de cera. Provando que há mários que vêm pra bem, ele revolucionou a interpretação, com seu estilo sincopado, indicativo de uma capacidade incomum de divisão rítmica. Misto de diseur e chanteur, Mário Reis mais diz do que canta. Revela, notavelmente, o canto da fala em vez do canto do falo (de voz potente e máscula). Isso explica porque, subitamente, ele, conduzido pela mão dos próprios bossa-novistas, retornou à cena no começo da década de 60. Tom Jobim compôs, em 1960, "Isso eu não faço, não" especialmente para Mário Reis. Aloysio de Oliveira, o mesmo produtor dos dois primeiros LPs de João Gilberto, produziu o seu primeiro LP, lançado nesse mesmo ano.

A modernidade de Noel Rosa foi outra constatação que se impôs no auge da Bossa Nova. Primeiro compositor a empregar o termo bossa numa canção de 1932 (“São coisas nossas"), Noel compreendeu como poucos o significado da mudança dos tempos e da entrada do rádio no circuito comercial, bem como da expansão 
do mercado para o disco. A associação de seu nome à modernidade correu solta entre os bossa-novistas. Jorge Caldeira, no livro Noel Rosa (1987, p. 78-79), lembrou que "seu jeito de cantar, a estilização que fez do samba e a modernidade das letras passaram a ser olhadas com outros olhos. Os revolucionários da Zona Sul apontavam Noel como um antecessor e, em livro, sua obra começou a ser avaliada pela via da modernidade de seus procedimentos". Para horror de Tinhorão, que considerava suspeita qualquer aproximação entre Noel e a Bossa Nova, insistiu-se no caráter coloquial do seu canto-falado e de suas letras, elementos que seriam retomados pela Bossa Nova. Se por modernismo, ligado à Semana de Arte Moderna, entendermos - segundo Affonso Romano de Sant'Anna em Música popular e moderna poesia brasileira (1986, p. 131) - o "esforço por tematizar aspectos da vida moderna”, implicando, entre outras coisas, "valorização do aspecto prosaico da vida e descrição do cotidiano real", mais do que nunca a canção de Noel Rosa era moderna, razão pela qual ainda foi realçado, nos anos 60, o quanto Chico Buarque carregava de Noel dentro de si.

O canto sem a afetação habitual era mais uma característica de renomados compositores do que propriamente dos cantores do rádio, assim como viria a ocorrer, pelo menos parcialmente, no período da Bossa Nova. Por outras palavras, é interessante verificar que a ligação entre o passado e o canto da Bossa Nova se dá mais por meio dos compositores, cuja projeção em geral era assegurada pelas interpretações de cantores reconhecidos como tais. Nesse caso se incluem, sob vários aspectos, Ataulfo Alves, Lamartine Babo, Ismael Silva e Geraldo Pereira, autores de músicas, a exemplo de outros compositores, que primavam pela letra coloquial. De Ataulfo Alves, mineiro de Miraí, Zona da Mata, e de seu samba, por exemplo, já disse Mário Lago que se tratava de algo diferente: "parece mineiro andando no meio da estrada, meio fingindo que não quer ir, mas indo" (apud LP/fascículo Ataulfo Alves, 1970, p. 9), o que se aplicava também, acrescento, à sua maneira descontraída de cantar.

Neste rápido inventário de elementos musicais tradicionais que seriam, posteriormente, retrabalhados e atualizados pela Bossa Nova, não poderia faltar, para concluir, uma referência ao samba-canção. No momento em que a Bossa Nova era gestada, o samba-canção, surgido em décadas passadas como uma espécie de samba de meio de ano, dominava a noite de centros urbanos mais desenvolvidos nos anos 50, como o Rio de Janeiro, com sua "música de boate". Uma parcela mais sofisticada do público consumidor de música, normalmente de extração social de classe média, identificava nele uma coisa de "bom-tom", inclusive pela assimilação de determinados componentes da música norte-americana. Apesar de descambar, por vezes, para o "sambolero" ou "sambalada" pouco significativos e, em casos extremados, dar aos dramas humanos um ar de dramalhão à mexicana, com direito a sangue $\mathrm{e}$ punhal, a produção mais consistente do samba-canção e o clima de intimidade que ele instalava propiciaram, até certo ponto, a aparição da Bossa Nova.

Música cantada em pequenos ambientes, associada, mais ou menos frequentemente, à cultura de fossa, as casas noturnas em que era ouvida serviram de escola para Tom Jobim e Johnny Alf, por exemplo, destaques nas noites cariocas e paulistanas. Cantores rotulados como "românticos", principalmente Dick Farney e Lucio Alves, muito lembrados como "precursores" pelos bossa-novistas, marcaram época na década de 50. Dick Farney, desde o início de sua carreira, deixava claro que calcava diretamente sua forma de expressão artística em modelos norte-americanos, tanto no jeito de cantar como de tocar piano. Isso se evidenciava até no nome: nascido Farnésio Dutra, projetou-se como Dick Farney (sintomaticamente, outro devorador das harmonias jazzísticas, Alfredo José da Silva, sócio do Sinatra-Farney Fã-Clube, seria batizado artisticamente como Johnny Alf). Compositora e cantora cercada de grande admiração, Dolores Duran - representativa do que aquele período tinha de melhor - enveredava inclusive pelo scat singing, no que viria a influenciar Leny Andrade, que até hoje a reverencia como sua "diva". O samba-canção expressava, enfim, como já observou o crítico José Lino Grünewald, um momento de internacionalização do samba "através do abandono da tipicidade dos instrumentos", enquanto "o ritmo se adapta a orquestrações com predominância de cordas”. 
Essas influências "estranhas" e "estrangeiras" iriam obviamente provocar críticas: a reação ao samba-canção representa, sob diversos aspectos, a antessala da reação à Bossa Nova. Não era para menos. Os Cariocas, o mais criativo conjunto vocal deste país, um dos emblemas da Bossa Nova, já em 1948 esmeravam-se na ousadia de harmonizações vocais dissonantes. Reprocessando elaborações de grupos vocais norte-americanos, eles se consagrariam como um marco no vocal brasileiro. Recolher, aqui ou ali, contribuições para dar vida à Bossa Nova não causava nenhum remorso nos pioneiros bossa-novistas. Como sintetizou Luiz Eça, "não tive nenhum muro de Berlim na minha formação musical", e por isso assimilava Beethoven, jazz ou Radamés Gnatalli, sem qualquer problema de má consciência. Os sonhos dourados dos adolescentes Roberto Menescal e Nara Leão eram embalados ao som de clássicos da música popular norte-americana. E tudo bem.

Tudo bem, coisa nenhuma. José Ramos Tinhorão e outros que tais botavam fogo pelas ventas. Não podiam assistir, impassíveis, a essa "intromissão indevida" do jazz e da música norte-americana em geral na música popular brasileira ou - o que dá no mesmo - o seu distanciamento das nossas "raízes". Num artigo sobre "Marcha e samba", publicado na Revista Civilização Brasileira, Tinhorão (1966, p. 261) demonstrava toda sua contrariedade com o que se poderia designar de involução do samba. Vale a pena acompanhar por alto a análise histórica do autor, cujo final é um monumento à ortodoxia:

Com o aparecimento de compositores profissionais dos meios de rádio e das fábricas de disco [...] o samba nascido carnavalesco foi adaptado pela modificação do seu andamento para o meio do ano sob o nome de sambacanção. [...] [Ele] foi progressivamente amolengando o ritmo até transformar-se, no correr da década de 1940, na pasta sonora que o confundiu praticamente com o bolero. [...] E foi assim que, quando o samba-canção cultivado pelos compositores profissionais de classe média passou a não comportar mais qualquer evolução formal, pelo esgotamento das possibilidades (ainda foram tentadas as sambaladas e os diferentes tipos de "balanços", inutilmente), surgiu no fim da década de 50 uma mudança de estrutura: o samba de bossa nova. Mas aí já se penetra na história do jazz e o autor deste artigo só gosta de falar de música popular brasileíra.

Samba-canção e Bossa Nova eram atirados às feras, depreciados como representantes da "corrupção" dos costumes musicais populares. Nada estranhável, partindo de quem elevava o "nacional-popular" (entenda-se, o nacional-populismo) à categoria de bem supremo.

\section{NOTAS}

1 Marco da Bossa Nova, "Chega de saudade", parceria de Antonio Carlos Jobim e Vinicius de Morais, foi gravada por João Gilberto em 10 de julho de 1958 nos estúdios da Odeon, no Rio de Janeiro, e lançada em $78 \mathrm{rpm}$ em agosto do mesmo ano.

2 A interpretação "definitiva" de "Influência do jazz" viria com a mais jazzística das cantoras da Bossa Nova, Leny Andrade, que dela extrai todas as consequências com um ar de quem não está nem aí com a denúncia da qual era portadora. Ouvir o LP A arte maior de Leny Andrade, de 1963. Ainda quanto a Carlos Lyra, é curioso lembrar que, após o golpe de 1964, ele, até então excessivamente preocupado com o resgate das "raízes populares" e com o "fundo elitista" da Bossa Nova, seguiu para os Estados Unidos, onde participou, lado a lado com Stan Getz, do Festival de Jazz de Newport. Sem falar na excursão internacional que ambos realizaram e nas apresentações de Carlos Lyra com o sexteto de jazz de Paul Winter. Apesar das "más influências" do jazz, nem por isso ele deixou de andar em "más companhias".

3 Franco Paulino inseria a obra de Vandré no movimento mais geral de busca da "nossa" realidade cultural. Sua "música participante brasileira" era entendida como um esforço bem-sucedido em favor de uma "canção de rua". O jornalista sintetizava a finalidade de Vandré, que despontara na própria Bossa Nova: "diminuir o vácuo existente, $\mathrm{e}$ cada vez maior, entre a realidade musical de nosso povo e o comportamento musical da maioria de nossos compositores de agora".

4 Diga-se, a bem de Sidney Miller, que na sequência do artigo ele atenua parcialmente esse brutal economicismo ao admitir que a Bossa Nova não deveria ser reduzida às transformações estruturais da classe média.

5 "Samba só" foi gravada primeiramente pelo seu autor, Walter Santos, em 1962, e, em seguida, por Claudete Soares. Registre-se que "quadrado" era a expressão pejorativa que a turma mais jovem da Bossa Nova usava para designar os cultores do passado e os que não iam além do samba tradicional. Já "sambalanço" representou a tentativa de Carlos Lyra de cunhar novo nome por antinomia aos "descaminhos" da Bossa Nova.

6 Xenófobo por convicção, Ary Barroso deplorou a Bossa Nova. Muito dado a sambas-exaltação, o ufanismo foi uma das marcas de suas composições. No entanto, a riqueza musical de suas criações transcendia ao criador, e a Bossa Nova o incorporou desde o primeiro LP 
de João Gilberto, que gravou "Morena boca de ouro" e "É luxo só".

7 Um pouco dessa história se acha no LP Jubileu de prata, do Trio Elétrico Dodô e Osmar. Não foi à toa que Caetano Veloso, em plena histeria antitropicalista, compôs "Atrás do trio elétrico" como mais uma peça de artilharia do debate cultural do fim dos anos 60: "Atrás do trio elétrico só não vai quem já morreu”, ou por outra, os mortos-vivos.

8 Já em 1968, na contracapa do seu primeiro LP tropicalista, Gilberto Gil ressaltava, num texto "psicografado" por Rogério Duarte: "Eu sempre estive nu. [...] E eu, do mais pobre de minha nudez, queria vestir todas [as roupas]. Todas, para não trair minha nudez. Mas eles gostam de uniformes".

9 O nacionalismo populista, como analisou Roberto Schwarz (1987) no ensaio "Nacional por subtração", lançou-se em "busca de um fundo nacional genuíno, isto é, não adulterado" (id., p. 32), meta que seria alcançada "através da eliminação do que não é nativo. O resíduo, nesta operação de subtrair, seria a substância autêntica do país” (id., p. 33). E ele se propunha questões que já algum tempo parecem inteiramente fora de propósito, se levarmos em consideração o desenvolvimento atingido pela indústria cultural em meio ao processo mais amplo de internacionalização do capital e da mercantilização da vida social. Mas, nos anos 60, relembra Schwarz, no front nacional-populista "reinava um estado de espírito combativo, segundo o qual o progresso resultaria de uma espécie de reconquista, ou melhor, da expulsão dos invasores" (id., p. 32). Ao menos para setores da esquerda nacionalista, "rechaçado o Imperialismo, neutralizadas as formas mercantis e industriais de cultura que lhe correspondiam, e afastada a parte antinacional da burguesia, aliada do primeiro, estaria tudo pronto para que desabrochasse a cultura nacional verdadeira, descaracterizada pelos elementos anteriores, entendidos como corpo estranho" (id.).

10 Uma revisão atual da obra de Garoto (Anibal Augusto Sardinha) que vale a pena ser ouvida está no LP Garoto, de Paulo Belinatti (nele este componente do Pau Brasil toca violão). Ouvir, especialmente, "Sinal dos tempos" e "Lamentos do morro", que soam à Bossa Nova. Ao mencionar os precursores da Bossa Nova, Aloysio de Oliveira (1989, p. 26 e 28) rememora que "já havia aquelas músicas estranhas do Custódio Mesquita, muita coisa do Ary Barroso e do Garoto, além das interpretações de Dick Farney e do Lucio Alves". Garoto, Johnny Alf, Dick, Lucio e outros mais figuram na lista de precursores de Roberto Menescal (1989, p. 25).

11 Para Sérgio Cabral (1989, p. 14), “o compositor e pianista Custódio Mesquita passou a usar em seus sambas-canções certos recursos até então utilizados apenas na música erudita e no jazz norte-americano". "Saia do caminho", uma das mais famosas criações da dupla Custódio Mesquita e Evaldo Rui, recebeu, por exemplo, nos últimos tempos, três gravações (de Gal Costa, de Nana Caymmi e de Tom Jobim e Miúcha) que capturaram muito bem as suas dissonâncias. Na versão que consta do LP Tom, Vinicius, Toquinho, Miúcha (gravado ao vivo no Canecão em 1977), atentar, particularmente, para a sutileza das dissonâncias admiravelmnente trabalhadas por Tom Jobim ao piano, com um colorido harmônico inusitado. "Nada além", de Custódio Mesquita e Mário Lago, sucesso na voz de Orlando Silva em 1938, é outra composição muito diferente dos padrões musicais da época: um fox do qual o clarinetista e saxofonista Paulo Moura, no seu LP Gafieira etc. \& tal, extraiu todo o seu potencial jazzístico, à la traditional jazz, à frente de um grupo em que se destaca o naipe de metais.

12 Uma retrospectiva da obra desse burguês revolucionário, que nem de longe precisava da música para se susentar, pode ser apreciada no LP Mário Reis - 1928/1978 - 50 anos de música. Nele reaparecem tanto gravações do período fundamental de sua carreita - que, a rigor, se estendeu pelo curto espaço de 1928 a 1936 - como outras mais recen- tes, da fase da Bossa Nova. Por sinal, os registros aí contidos de "Isso eu não faço não" (Tom Jobim) e de "O grande amor" (Tom Jobim e Vinicius de Morais), que vieram a público no LP Mário Reis canta suas criações em hi-fi, fazem nitidamente o estilo bossa-novista.

13 Noel Rosa encontrou em Aracy de Almeida e Marilia Batista intérpretes destacadas para suas composições. Embora ele não fosse exatamente um cantor de sucesso, esta sua faceta, menos conhecida, não deve, de forma alguma, ser menosprezada. Ouvir, entre outros, o LP Uma rosa para Noel - 50 anos depois, com gravações realizadas entre 1931 e 1933, num disco em que o maestro Edson José Alves reconstitui instrumentalmente os arranjos originais, conservando-se intacta a voz de Noel Rosa.

14 Para a análise da modernidade de sua obra, ver o ensaio "As origens do samba, Noel Rosa e o modernismo", de Affonso Romano de Sant'Anna (1986).

15 Limito-me, aqui, a dois exemplos. Ataulfo Alves teve suas canções gravadas desde 1933, mas apenas aparece cantando em 1940, emplacando em 1942 o sucesso "Ai, que saudades da Amélia" (dele e Mário Lago). O LP Ataulfo Alves, 80 anos põe em evidência a simplicidade do seu canto, com finais que nada têm de grandiloquentes. A propósito, ouvir "Pois é", de 1955, composição de sua autoria, cujo desfecho cativa pelo tom extremamente coloquial. Quanto a Lamartine Babo, basta afirmar - e isso vale por um elogio - que em "A tua vida é um segredo", dele próprio, praticamente se confundem as vozes dos intérpretes, ele e Mário Reis. Um adendo: nem só de compositores que cantavam se compõe esse quadro. Dentre aqueles considerados acima de tudo como cantores, podemos identificar, aqui e ali, alguns que não se conformavam à regra geral, como um Blecaute ou mesmo um Jorge Veiga. 16 Ouvir performances de ambos no LP Dick Farney \& Lucio Alves. Nora Ney era outra artista de sucesso que, com voz cálida, cantava aos sussurros, conferindo às suas inerpretações um toque dramático mais contido. Certos traços comuns, de estilo intimista, aproximavam, aliás, alguns dos melhores intérpretes do samba-canção, como ainda foi o caso de Maysa e de Tito Madi, ambos despontando em meados dos anos 50. Nora Ney converteu-se, diga-se de passagem, numa das cantoras privilegiadas do cronista Antonio Maria, cujas composições contêm registros de flagrantes sentimentais da boemia carioca, "música da noite" para cotovelos à flor da pele. Ouvir, por exemplo, os LPs Tom Jobim e Billy Blanco, Antonio Maria \& Fernando Lobo, nos quais figuram gravações de Nora Ney, Maysa e Chove lá fora e outros sucessos de Tito Madi. São todos eles coletâneas que reúnem as matrizes originais de gravações da década de 50, exceção feita a Dick Farney, do qual constam ambém dois sucessos dos anos 40 .

$17 \mathrm{O}$ cantor Dick Farney, nos seus primeiros passos, se mostra de corpo inteiro no LP O começo, no qual foram juntadas gravações originais que vão de 1944 a 1952.

18 No registro do samba-canção "Fim de caso", de sua autoria, Dolores Duran exibia o seu domínio vocal das improvisações jazzísticas, tipo scat siging, do mesmo modo como na rumba "Ave Maria Lola", de Sergio G. Siaba. A incorporação de elementos do jazz à sua interpretação é absolutamente clara em "My funny Valentine", de R. Rodgers e L. Hart. Para atestar sua competência e sensibilidade interpretativa, nada mais eloquente do que a opinião de Ella Fizgerald, uma expert em scat singing. Durante passagem pelo Brasil nos anos 50, ela dirigiu-se à boate Bacarat especialmente para ouvir Dolores. Ao final, não se fez de rogada: "foi esta a melhor interpretação que já ouvi de 'My funny Valentine"” (apud LP/fascículo Dolores Duran/Tito Madi, 1970, p. 1), um standard da música norte-americana com inumeráveis gravações de alta qualidade. Leny Andrade, que por sua vez deglutiu influências de Dolores Duran e Ella Fitzgerald, admite, implicitamente, ter 
chegado ao jazz via Dolores, a quem sempre admirou. Ouvir o seu depoimento no LP Leny Andrade, de 1984, faixa “O negócio é amar", música de Carlos Lyra colocada sobre um poema póstumo de Dolores Duran caracterizado pelo texto francamente coloquial, muito ao seu estilo.

19Fundado nos anos 40, sob a liderança de Ismael Neto, falecido em 1956, o conjunto passou, desde então, a ter como líder seu irmão Severino Filho e, na década de 60, abandonou sua formação de quinteto para transformar-se em quarteto, completado por Quartera, Badeco, integrantes remanescentes, mais Luiz Roberto. Suas duas primeiras gravações datam de 1948, "Nova ilusão” (Luiz Bittencourt e José Menezes) e "Adeus, América" (Geraldo Jacques e Haroldo Barbosa), e destoam muito da maneira como cantavam à época os conjuntos vocais, embora não se deva desconsiderar a relativamente inovadora presença de alguns grupos, como, por exemplo, Os Namorados da Lua, à frente do qual estava o crooner Lucio Alves, familiarizado com as vocalizações de conjuntos norte-americanos. Ouvir, sobre o assunto, a coletânea Os grandes conjuntos vocais brasileiros. Mesmo grupos vocais/instrumentais mais tradicionais chegaram a gravar o que se rotulou, no início dos anos 40, como samba-swing, um exemplo dos novos ares que bafejavam a música popular brasileira: ouvir "Pesadelo" (Janet de Almeida e Léo Vilar), com os Anjos do Inferno, e "Coisas do carnaval" (Ary Barroso), com os 4 Azes e 1 Coringa.

20 A recordação musical desse período, quando Nara e Menescal eram colegas de turma de praia do Posto 4 de Copacabana, está viva no LP Meus sonhos dourados, de Nara Leão, com Roberto Menescal na direção de produção, guitarra e violão. Todas as canções aí incluídas receberam um tratamento bossa-novista, distinguindo-se pela delicadeza de interpretação e arranjo, em versões livres para o português, lançadas originalmente no mercado japonês.

\section{FONTES E REFERÊNCIAS BIBLIOGRÁFICAS}

ANDRADE, Oswald de. Manifesto Antropófago. Revista de Antropofagia, São Paulo, no 1, maio 1928.

BARROS, Nelson Lins e. Música popular e suas bossas. Movimento, Rio de Janeiro, n 6, out. 1962.

CABRAL, Sérgio. A Bossa Nova. In: CHEDIAK, Almir (prod.). Bossa Nova, vol. 1. Rio de Janeiro: Lumiar, 1989.

CALDEIRA, Jorge. Noel Rosa. $3^{\text {a }}$ ed. São Paulo: Brasiliense, 1987.

CAMPOS, Augusto de (org.). Balanço da bossa e outras bossas. $4^{\mathrm{a}}$ ed. São Paulo: Perspectivas, 1986.

CHAUI, Marilena. Conformismo e resistência: aspectos da cultura popular no Brasil. São Paulo: Brasiliense, 1986.

CHEDIAK, Almir (prod.). Songbook Bossa Nova, vols. 1, 2 e 3. Rio de Janeiro: Lumiar, 1989.

CORDEIRO, Cruz. Comentários sobre "Lamentos" e "Carinhoso”. Phono-Art, Rio de Janeiro, nov. 1928 e jan. 1929.
DONATO, João. Entrevista. In: CHEDIAK, Almir (prod.). Bossa Nova, vol. 3. Rio de Janeiro: Lumiar, 1989.

ELOMAR. Entrevista concedida a FREITAS, Terezinha A. de. "Elomar, um imprensado entre dois rolos compressores". Jornal da Adufu, Uberlândia, nº 16, set. 1987, p. 11.

GIL, Gilberto. Conversa com Gilberto Gil. In: CAMPOS, Augusto de (org.). Balanço da bossa e outras bossas. $4^{\text {a }}$ ed. São Paulo: Perspectivas, 1986.

MENESCAL, Roberto. Entrevista. In: CHEDIAK, Almir (prod.). Bossa Nova, vol. 1. Rio de Janeiro: Lumiar, 1989.

MILLER, Sidney. O universalismo e a música popular brasileira. Revista Civilização Brasileira, Rio de Janeiro, no 21/22, set.-dez. 1968.

MORAES, J. Jota de. Música da modernidade: origens da música do nosso tempo. São Paulo: Brasiliense, 1983.

OLIVEIRA, Aloysio de. Entrevista. In: CHEDIAK, Almir (prod.). Bossa Nova, vol. 1. Rio de Janeiro: Lumiar, 1989.

REVISTA DA MÚSICA POPULAR, Rio de Janeiro, n 1 , set. 1954.

ROMERO, Silvio. Machado de Assis. Rio de Janeiro: Laemmert, 1897.

ROUANET, Sergio Paulo. Nacionalismo, populismo e historismo. Folha de S. Paulo, 12 mar. 1988, p. D-3.

SANT'ANNA, Affonso Romano de. "As origens do samba, Noel Rosa e o modernismo". In Música popular e moderna poesia brasileira. 3a ed. Petrópolis: Vozes, 1986.

SCHWARZ, Roberto. Nacional por subtração. In: Que horas são?: ensaios. São Paulo: Companhia das Letras, 1987.

TINHORÃO, José Ramos. Música popular: um tema em debate. Rio de Janeiro: Saga, 1966.

. Marcha e samba. Revista Civilização Brasileira, Rio de Janeiro, no 8, jul. 1966.

Pequena história da música popular: da modinha ao tropicalismo. $5^{\text {a }}$ ed. São Paulo: Art, 1986.

. A montagem brasileira da bossa nova e o protesto musical universitário. In: História social da música popular brasileira. Lisboa: Caminho, 1990.

VÁRIOS autores. Violão de rua, vols. I, II e III: Poemas para a liberdade. Rio de Janeiro: Civilização Brasileira, 1962-1963.

VELOSO, Caetano. Que caminho seguir na música popular brasileira? (debate). Revista Civilização Brasileira, Rio de Janeiro, $\mathrm{n}^{\circ}$ 7, maio 1966. 


\section{REFERÊNCIAS DISCOGRÁFICAS}

"A tua vida é um segredo" (Lamartine Babo), Lamartine Babo e Mário Reis. 78 rpm RCA Victor, 1933.

"Adeus, América" (Geraldo Jacques e Haroldo Barbosa), Os Cariocas. $78 \mathrm{rpm}$ Continental, 1948.

"Ai, que saudades da Amélia" (Ataulfo Alves e Mário Lago), Ataulfo Alves e sua Academia de Samba. 78 rpm Odeon, 1942.

"Atrás do trio elétrico" (Caetano Veloso), Caetano Veloso. LP Caetano Veloso. Philips, 1969.

“Ave Maria Lola” (Sergio G. Siaba). Dolores Duran. 78 rpm Copacabana, 1959.

CABRAL, Sérgio. Falando de samba e de bambas. LP/fascículo Bide, Marcal \& Paulo da Portela. História da música popular brasileira. São Paulo: Abril Cultural, 1984.

“Carinhoso" (Pixinguinha), Orquestra Típica Pixinguinha-Donga. 78 rpm Parlophon, 1928.

"Chão de estrelas" (Silvio Caldas e Orestes Barbosa), Mutantes. LP A divina comédia ou ando meio desligado. Polydor, 1970.

"Chega de saudade" (Antonio Carlos Jobim e Vinicius de Morais), João Gilberto. 78 rpm Odeon, 1958.

"Coisas do carnaval" (Ary Barroso), 4 Azes e 1 Coringa. 78 rpm Odeon, 1942.

"É luxo só" (Ary Barroso e Luiz Peixoto), João Gilberto. LP Chega de saudade. Odeon, 1959.

"Épico" (Caetano Veloso), Caetano Veloso. LP Araçá azul. Philips, 1972.

"Fim de caso" (Dolores Duran), Dolores Duran. 78 rpm Copacabana, 1959.

GIL, Gilberto. Texto da contracapa do LP Gilberto Gil. Philips, 1968.

"Influência do jazz" (Carlos Lyra), Carlos Lyra. LP Sambalanço de Carlos Lyra. Philips, 1962.

Leny Andrade. LP A arte maior de Leny Andrade. Polydor, 1963.

"Isso eu não faço, não" (Tom Jobim), Mário Reis. LP Mário Reis canta suas criações em hi-fi. Odeon, 1960.

LP Ataulfo Alves, 80 anos. Ataulfo Alves. EMI-Odeon, 1989.

LP Chega de saudade. João Gilberto. Odeon, 1959.

LP Chove lá fora e outros sucessos de Tito Madi. Tito Madi. Phonodisc, 1987.

LP Dick Farney \& Lucio Alves. Dick Farney e Lucio Alves. Continental, 1974
LP Jubileu de prata. Trio Elétrico Dodô e Osmar. Continental, 1974.

LP Mário Reis - 1928/1978 - 50 anos de música. Mário Reis. EMI-Odeon/Fênix, s./d.

LP Maysa. Maysa. RGE, 1979.

LP Meus sonhos dourados. Nara Leão. Philips, 1987.

LP O começo. Dick Farney. Phonodisc, 1988.

LP Os grandes conjuntos vocais brasileiros. Vários intérpretes. Continental, 1976.

LP Tom Jobim e Billy Blanco. Vários intérpretes. Continental, 1975.

LP Uma rosa para Noel - 50 anos depois. Noel Rosa. Continental, 1987.

LP/fascículo Antonio Maria \& Fernando Lobo. História da Música Popular Brasileira. Vários intérpretes. São Paulo: Abril Cultural, 1983

LP/fascículo Ataulfo Alves. História da Música Popular Brasileira. Vários intérpretes. São Paulo: Abril Cultural, 1970.

LP/fascículo Dolores Duran/Tito Madi. História da Música Popular Brasileira. Vários intérpretes. São Paulo: Abril Cultural, 1970.

"Lamento" (Pixinguinha), Orquestra Típica Pixinguinha-Donga. 78 rpm Parlophon, 1928.

"Lamentos do morro" (Garoto), Paulo Belinatti. LP Garoto. Marcus Pereira, 1986.

"My funny Valentine" (R. Rodgers e L. Hart). Dolores Duran. Compacto duplo Dolores Duran no Michel de São Paulo. Copacabana, 1959.

"Morena boca de ouro" (Ary Barroso), João Gilberto. LP Chega de saudade. Odeon, 1959.

"Nada além” (Custódio Mesquita e Mário Lago), Orlando Silva. 78 rpm RCA Victor, 1938.

, Paulo Moura. LP Gafieira etc. \& tal. Kuarup, 1986.

"Nova ilusão" (Luiz Bittencourt e José Menezes), Os Cariocas. 78 rpm Continental, 1948.

"O grande amor" (Tom Jobim e Vinicius de Morais), Mário Reis. LP Mário Reis canta suas criações em hi-fi. Odeon, 1960.

"O negócio é amar" (Carlos Lyra e Dolores Duran), Leny Andrade. LP Leny Andrade. Pointer, 1984.

PAULINO, Franco. Texto da contracapa do LP 5 anos de canção. Geraldo Vandré. Som Maior, 1966.

"Pesadelo" (Janet de Almeida e Léo Vilar), Anjos do Inferno. 78 rpm Columbia, 1943. 
"Pois é" (Ataulfo Alves), Ataulfo Alves e suas Pastoras. 78 rpm Sinter, 1955.

RANGEL, Lucio. Texto da contracapa do LP Descendo o morro. Roberto Silva. Copacabana, 1958.

RANGEL, Lucio. Texto da contracapa do LP Descendo o morro $n^{\circ}$ 2. Roberto Silva. Copacabana, 1959.

"Saia do caminho" (Custódio Mesquita e Evaldo Rui), Gal Costa. CS Philips, 1974.

Nana Caymmi. LP Atrás da porta, CID, 1977.

Tom Jobim e Miúcha. LP Tom, Vinicius, Toquinho, Miúcha. Som Livre, 1977.

"Samba só" (Walter Santos e Tereza Souza), Claudete Soares. LP A dona da Bossa. Mocambo, 1963.

Walter Santos. LP Bossa Nova. Audio Fidelity, 1962.

"São coisas nossas" (Noel Rosa), Noel Rosa. 78 rpm Columbia, 1932.

SARGENTELLI. Participação no LP Depoimento do poeta. Nelson Cavaquinho. Castelinho, 1970.

SARMENTO, Rubens Moraes. Hoje é dia de samba. Texto da contracapa do LP Saudade em forma de samba. Roberto Silva. Copacabana, 1966.
"Sinal dos tempos" (Garoto), Paulo Belinatti. LP Garoto. Marcus Pereira, 1986.

SOUZA, Tárik de. Em constante busca da simplicidade. LP/fascículo Caymmi. História da música popular brasileira. São Paulo: Abril Cultural, 1982.

\section{OUTRAS REFERÊNCIAS}

ELOMAR. Entrevista ao programa “Arrumação", TV Minas, s./d.

\section{O AUTOR}

Adalberto Paranhos é Mestre em Ciência Política pela Universidade Estadual de Campinas (Unicamp) em 1997. Doutor em História Social pela Pontifícia Universidade Católica de São Paulo (PUC-SP) em 2005. Realizou estágio pós-doutoral em Música da Unicamp, entre 2014 e 2015, sob a supervisão de José Roberto Zan. Professor associado da Universidade Federal de Uberlândia (UFU), na qual atua nos cursos de graduação em Ciências Sociais, na graduação em Música e no Programa de Pós-graduação em História. Bolsista produtividade em pesquisa do CNPq. Professor visitante da Universidade de Lisboa. Editor de ArtCultura: Revista de História, Cultura e Arte, periódico do Instituto de História, vinculado ao Programa de Pós-graduação em História da UFU. 